\title{
Influence of pre-hardening duration and dehardening temperatures on varietal freezing resistance in faba beans (Vicia faba L.)
}

\author{
H. Herzog \\ Institute of Crop Science and Plant Breeding. University of Kiel, Olshausenstr. 40, D-2300 Kiel 1, FRG
}

(received 18-12-1987, accepted 11-10-1988)

Summary - Hardening response of winter faba beans at $8 / 2^{\circ} \mathrm{C}$ (day/night) to pre-hardening periods at $15^{\circ} \mathrm{C}$ of different length (3-11 days after plant emergence) and dehardening at various temperatures $\left(7-15^{\circ} \mathrm{C}\right)$ was examined in a series of experiments with 9 European varieties through detached leaf tests. Extending the pre-hardening period lowered the level of acquired freezing resistance (FR) in the first leaf (lowest one) and obviously shortened the phase of linear increase $\left(\triangle F R \approx 0.4^{\circ} \mathrm{C} /\right.$ day $)$. The level of FR in the second (and third) leaf always exceeded that in the first one and differences between them were most prominent under longer periods of prehardening, suggesting that the potential FR in a leaf can be attained only if hardening has already started at the onset of leaf expansion.

The dehardening process started without any lag at temperatures above $8.5^{\circ} \mathrm{C}$, and the decline in FR was steeper at the beginning than at later stages. The initial rates of decline depended on the ambient temperatures and ranged between $3-0.7^{\circ} \mathrm{C} /$ day at 15 and $8.5^{\circ} \mathrm{C}$, respectively. At temperatures around $7^{\circ} \mathrm{C}$ acquired $\mathrm{FR}$ remained almost constant.

Varietal differences in hardened plants amounted to $1-2^{\circ} \mathrm{C}$ and were maximally expressed with short prehardening. Superior to all varieties was the old French land race Côte d'Or (resistance $\approx-16^{\circ} \mathrm{C}$ ); nevertheless, considerable differences were also evident between the other varieties. The varietal rank pattern was consistent in different leaves if taken from the same plants, but did not completely agree between different experiments when 15 or less plants of a variety were used. Hence more than 15 plants are regarded as necessary to obtain reliable values of varietal FR. The varietal rank pattern of fully hardened plants remained almost unchanged during partial dehardening. These results are discussed with regard to their significance for crop production and plant breeding.

cold hardening/dehardening - varietal freezing resistance - differential leaf response - winter beans - Vicia faba L.

Résumé - L'influence de la durée de la phase précédant l'endurcissement et de diverses températures après l'endurcissement sur la résistance variétale au froid chez la féverole d'hiver. Dans une série d'expériences en enceinte climatique on a étudié la résistance au froid sur 9 variétés européennes de féverole d'hiver par un test aux feuilles détachées (1) pendant l'endurcissement à $8 / 2^{\circ} \mathrm{C}$ (jour/nuit) des durées différentes à $15^{\circ} \mathrm{C}$ (3-11 jours de préendurcissement) et (2) désendurcissement des températures différentes $\left(7-15^{\circ} \mathrm{C}\right)$. Une prolongation de la phase précédant l'endurcissement diminue le degré maximum de résistance de la première feuille, évidemment par une réduction de la durée de la phase de l'augmentation linéaire $\left(0,4^{\circ} \mathrm{C} / \mathrm{jour}\right.$. Le niveau de résistance de la deuxième et troisième feuille est plus élevé que celui de la première feuille et les différences sont particulièrement grandes pour une longue phase de pré-endurcissement (8-11 jours). La perte de résistance commence sans retard pour des températures supérieures à $8,5^{\circ} \mathrm{C}$ et la vitesse est plus grande au début qu'à la fin. La vitesse initiale dépend de la température ambiante et varie entre $3-0,7^{\circ} \mathrm{C} / j$ our à $15^{\circ} \mathrm{C}$ et $8,5^{\circ}$ respectivement. $A$ une température de $7^{\circ} \mathrm{C}$, la résistance au froid reste à peu près constante. Les différences de résistance entre les variétés après l'endurcissement se situent entre $1-2^{\circ} \mathrm{C}$ et sont particulièrement developpées après une courte phase de pré-endurcissement. La vieille race française Côte d'Or s'avère supérieure à toutes les autres variétés (résistance $\approx-16^{\circ} \mathrm{C}$ ), bien qu'entre ces dernières il y ait aussi des différences considérables. L'ordre de classement des variétés est inchangé entre les différentes feuilles quand elles sont prélevées sur les mêmes plantes, mais n'est plus le même pour des échantillons différents de 15 plantes ou moins par variété. Par conséquent il faudrait utiliser plus de 15 plantes pour améliorer la détermination de la résistance variétale. Le classement des variétés chez des plantes endurcies est identique à celui de plantes partiellement désendurcies. Ces résultats sont discutés pour leur importance en agronomie et en amélioration des plantes.

résistance au froid/(des) - endurcissement, réponse variétale - réponse de feuilles - féverole d'hiver - Vicia faba $L$. 


\section{Introduction}

Because of harvest difficulties resulting from a long vegetation period in north-western Europe and because of a considerable susceptibility to water deficits during the extended flowering period, early flowering and ripening are some of the most urgent aims in breeding of faba beans. However, these aims are probably in contrast with attempts to raise the yield potential of this crop. Solution of this conflict may be sought in breeding of winter forms which partially avoid water deficits by developing deeper root systems (Heath and Hebblethwaite, 1985) and by earlier flowering and maturity (Herzog, 1984).

To date, growing of winter faba beans is restricted to small areas with mild winters in France and Great Britain because of low freezing resistance in the available cultivars. A recent report on 5 European cultivars (Herzog, 1987b) showed that freezing resistance attained a level of -11 to $-12^{\circ} \mathrm{C}$ after $2-3$ weeks of hardening at $8 / 2^{\circ} \mathrm{C}$ (day/night), when emerging seedlings had been grown at non-hardening temperatures before (i.e., pre-hardening at $15^{\circ} \mathrm{C}$ ). Moreover, these investigations confirmed previous studies (Herzog, 1980), suggesting that the individual leaves of a plant pre-hardened at 15 or $20^{\circ} \mathrm{C}$ responded differently to hardening. These findings led to the assumption that the stage of differentiation in leaves at the onset of hardening might limit their response to hardening. If so, this behaviour is of crucial importance in determining optimum sowing time of faba beans in fall. Hence the decision was made to reexamine this hypothesis and to increase the number of varieties (or populations) since differences in maximum freezing resistance among 5 European winter faba beans had proved to be remarkably small (Herzog, 1980, 1987b). Another objective was to elucidate the stability of freezing resistance under various dehardening temperatures, since field trials in Northern Germany had shown that winter survival was severely restricted in several cases at the end of winter.

\section{Material and Methods}

A series of 6 experiments was performed in a growth chamber with 9 European winter faba beans: 3 French (cv. Avrissot; the land race Côte d'Or; and cv. Survoy/obtained from INRA; Le Rheu), 3 British (cvs. Banner; Bourdon; and Bulldog/NSDO, Cambridge) and 3 German (cv. Hiverna; a population NP; and Webo/Littmann, Malente/Norddeutsche Pflanzenzucht,
Hohenlieth/Lochow-Pettkus, Bergen). In Figures 3 and 4 the populations are referred to as $\mathrm{Av}, \mathrm{Co}, \mathrm{Su}, \mathrm{Ba}, \mathrm{Bo}$, $\mathrm{Bu}, \mathrm{Hi}, \mathrm{NP}$, and $\mathrm{We}$.

Seeds were soaked in tap water and pre-germinated on moist quartz sand at $20-22^{\circ} \mathrm{C}$ for $3-4$ days. Uniform seedlings with radicle length of $2-3 \mathrm{~cm}$ were transplanted in cubic plastic pots $(17 \times 17 \times 17 \mathrm{~cm})$ filled with $6 \mathrm{~kg}$ of loamy sand mixed with $3 \%$ peat $(w / w)$ which was initially watered with $500 \mathrm{ml}$ of a modified half-strength Hoagland solution and, later on with tap water every other day. Twenty-five seedlings were raised per pot and thinned to 20 after a short pre-hardening period of 11 (expt. 1), 8 (expt. 2), 7 (expt. 5), or 3 days (expts. 3 and 4) in a growth chamber (Bioclim $1600 \mathrm{Sp}$, Weiss $\mathrm{GmbH}, \mathrm{FRG}$ ) at $15^{\circ} \mathrm{C}$. A photon flux density of $350 \mu \mathrm{mol}$ $\mathrm{m}^{-2} \mathrm{~s}^{-1}(400-710 \mathrm{~nm})$ was provided daily for $10 \mathrm{~h}$ by cool white lamps and Fluora lamps (Osram). After prehardening, the temperature was lowered to $8 / 2^{\circ} \mathrm{C}$ (day/night) for 4-7 weeks of hardening; the subsequent dehardening was performed at $15^{\circ} \mathrm{C}$ (expts. 2 and 3 ), $10^{\circ} \mathrm{C}$ (expt. 4), and $8.5^{\circ} \mathrm{C}$ (expt. 5). In a further experiment (6) fully hardened plants were partially dehardened at $8.5^{\circ} \mathrm{C}$ for 2 days, and then exposed to $7^{\circ} \mathrm{C}$ to see if the latter regime would lead to an increase or decrease of freezing resistance. In experiments 5 and 6 temperatures at night were $1^{\circ} \mathrm{C}$ higher than those during the day, due to technical problems.

Freezing resistance of detached leaves was examined in terms of $R_{50}$ values indicating the temperature at which a moderate injury occurred. Injury was assessed by visual rating after standardized freeze-thaw cycles at definite test-temperatures (TT) and was transformed to $R_{50}$ values. The method for assessing freezing resistance has recently been described in detail (Herzog, 1987a). The frequency of samplings was adjusted according to the changes in FR expected or observed previously. In order to increase the number of samplings from a limited number of plants $(\approx 40 /$ pop.), the 2 leaflets of bifoliate leaves were used for different sampling dates. However, regarding the determination of mean varietal FR, only true replicates (i.e., different plants, Figs. 3 and 4) were compiled. Data were subjected to 2- and 3-factor analysis of variance. LSD and varietal ranks were computed at $P=0.05$ with the Student-Newman-Keuls test. Linear sections of the time-course of FR (Figs. 1 and 2) were computed according to the maximum likelihood method and nonlinear sections were eye-fitted. Initial rates of dehardening or hardening were calculated from the first measurements of FR and from basic FR. The latter values represents the lowest possible FR in leaves developing at temperature at/above $15^{\circ} \mathrm{C}$ and were obtained from Herzog (1987b).

\section{Results}

From previous experiments with hardening at $8 / 2^{\circ} \mathrm{C}$ (Herzog, $1980,1987 \mathrm{~b}$ ) it was assumed that freezing resistance (FR) would increase almost linearly for at least 14-20 days. Hence, examinations were begun after 10-14 days of hardening when the first leaves had almost expanded. 

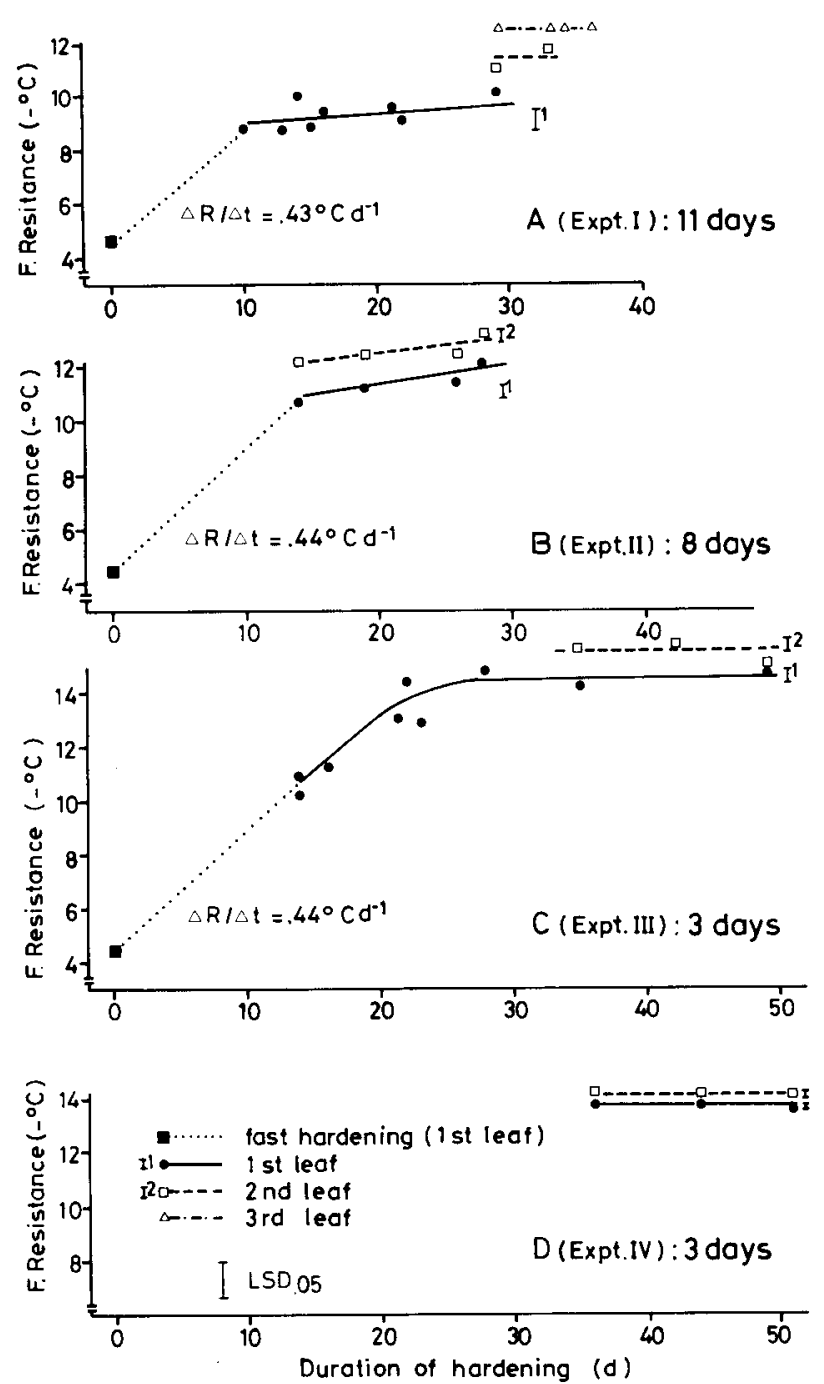

Fig. 1. Influence of the pre-hardening duration at $15^{\circ} \mathrm{C}$ (A-D) on the development of freezing resistance* in lower leaves of faba beans during hardening at $8 / 2^{\circ} \mathrm{C}$ ("means of 9 varieties and 5 replicates, values at day 0 ( $\square$ ) were adopted from Herzog 1987b; for further details, see Materials and Methods).

However, almost no or just a slight increase in FR was observed in the first leaf if pre-hardening at $15^{\circ} \mathrm{C}$ lasted for 11 or 8 days (Fig. 1A,B). After 3 days of pre-hardening, a linear increase of $0.44^{\circ} \mathrm{C} /$ day was still perceptible between day 14 and 21 (Fig. 1C). Initial rates of hardening (Fig. $1 \mathrm{~A}-\mathrm{C})$ calculated from the first measurements of FR and basic FR at day 0 , also amounted to $0.43-0.44^{\circ} \mathrm{C} /$ day, regardless of the different prehardening conditions. However, shortening the period of pre-hardening obviously prolonged the duration of linear increase in FR from 10 to 14 or
21 days respectively, and led to an improvement in maximum FR. The latter fact became more evident when data after the third week of hardening was compiled (Table I). In addition, this compilation revealed that shortening of pre-hardening also lessened the differences between the first and second leaf.

Dehardening was first studied in experiment 2 at a temperature of $15^{\circ} \mathrm{C}$, known to be ineffective in hardening. Surprisingly, this temperature provoked a dramatic decline within 4-5 days, so test temperatures in the freeze-thaw cycles had been adjusted too high to allow exact computation of FR values. Based on this experience, however, dehardening at $15^{\circ} \mathrm{C}$ could be monitored correctly in experiment 3 (Fig. 2), indicating that the greater part of maximum resistance was lost in as little as 2-3 days. The decline rate initially was about $3^{\circ} \mathrm{C} /$ day and obviously decreased with time. A similar but flatter curve of dehardening was established at $10^{\circ}$ or $8.5^{\circ} \mathrm{C}$. The initial rates were 1.2 and $0.7^{\circ} \mathrm{C} /$ day, respectively. Generally, leaves 1 and 2 responded quite similarly even if their maximum FR differed considerably (dehardening at $8.5^{\circ} \mathrm{C}$; Fig. 2).

To examine the effects of approximately $7^{\circ} \mathrm{C}$, fully hardened plants were first slightly dehardened at $8.5^{\circ} \mathrm{C}$ for 2 days and then exposed to $7^{\circ} \mathrm{C}$ for 3 weeks. There was only a hardly perceptible decrease in $\mathrm{FR}$, which averaged $<0.1^{\circ} \mathrm{C} /$ day.

The effects of pre-hardening conditions on the mean varietal FR in the lowest leaves were examined during intervals when an almost constant level was attained (Figure 3; compare also Figure 1). When leaves 1 and 3 were sampled from different plants considerable deviations in the varietal rank pattern became evident (Fig. $3 A)$. Contrary to leaf 3 which showed 2 different groups of varieties, in leaf 13 groups could be distinguished and Bulldog and NP appeared to be significantly more resistant than Banner and Webo, respectively.

In principle these deviations in the varietal pattern between leaves 1 and 3 might be ascribed either to a different expression of the potential resistance due to different environments to which these leaves had been exposed during their ontogenesis and/or simply to variation of resistance between plants chosen from the populations. In order to exclude the latter possibility, leaves 1 and 2 were simultaneously sampled from the same plants in the other experiments (Fig. 3B-D). No significant interactions between leaves and varieties were established under these circumstances. 
Table I. Effects of pre-hardening duration on the acquired freezing resistance (FR) and the differences between the two lower leaves $(\triangle F R)$ of faba beans after more than 3 weeksof hardening at $8 / 2^{\circ} \mathrm{C}$

\begin{tabular}{|c|c|c|c|c|c|c|c|c|}
\hline \multirow[t]{2}{*}{ Expt. } & \multicolumn{2}{|c|}{ Sampling } & \multicolumn{2}{|c|}{ Duration of $(d)$} & \multirow[t]{2}{*}{ Leaf No. } & \multirow[t]{2}{*}{$F R\left(-^{\circ} \mathrm{C}\right)$} & \multirow[t]{2}{*}{$L S D(P=0.05)$} & \multirow[t]{2}{*}{$\Delta F R(1-2)$} \\
\hline & size & date* & $\begin{array}{l}\text { germination } \\
\text { at } 20^{\circ} \mathrm{C}\end{array}$ & $\begin{array}{l}\text { pre-hardening } \\
\text { at } 15^{\circ} \mathrm{C}\end{array}$ & & & & \\
\hline 1 & 27 & 29 & 3 & 11 & $\begin{array}{l}1 \\
2 \\
3\end{array}$ & $\begin{array}{l}10.00 \\
11.55 \\
12.48\end{array}$ & 0.49 & 1.55 \\
\hline 2 & 108 & $26-28$ & 4 & 8 & $\begin{array}{l}1 \\
2\end{array}$ & $\begin{array}{l}11.85 \\
12.92\end{array}$ & 0.57 & 1.07 \\
\hline 5 & 135 & $23-31$ & 4 & 7 & $\begin{array}{l}1 \\
2\end{array}$ & $\begin{array}{l}12.56 \\
13.68\end{array}$ & 0.34 & 1.12 \\
\hline 3 & 135 & $29-49$ & 3 & 3 & $\begin{array}{l}1 \\
2\end{array}$ & $\begin{array}{l}14.58 \\
15.47\end{array}$ & 0.22 & 0.89 \\
\hline 4 & 135 & $36-51$ & 3 & 3 & $\begin{array}{l}1 \\
2\end{array}$ & $\begin{array}{l}13.98 \\
14.37\end{array}$ & 0.21 & 0.39 \\
\hline
\end{tabular}

^Days after onset of hardening.

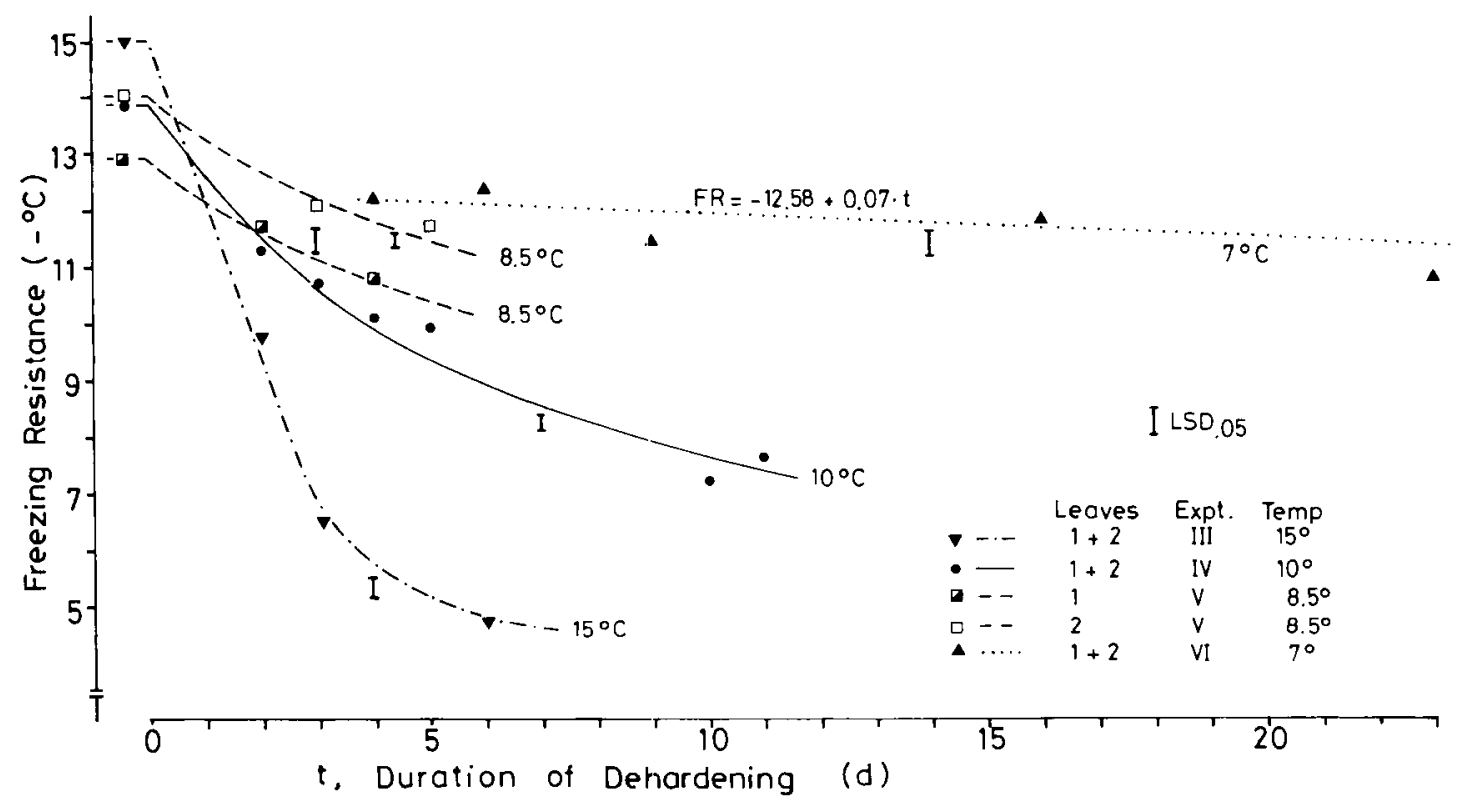

Fig. 2. Dehardening * of the 2 lowest leaves of faba beans at 4 different temperature regimes (" means of 9 varieties and 5 replicates; for details, see Materials and Methods).

That small numerical deviations in the performance of both leaves were indeed due to chance, was supported by their inconsistency among the 3 experiments (e.g., Avrissot: difference between leaves 1 and 2 compared to the other varieties was relatively large in expt. 2 , but small in expts. 3 . and 4).

Although the varietal pattern in freezing resist- ance averaged over both leaves roughly agreed in expts. 2, 3 and 4, some changes in the ranks between single varieties were noticeable. Thus Bourdon tended to have a lower resistance than Survoy in experiments 2 and 3 , but was significantly more resistant in experiment 4 . A similar change in ranks could be observed in the relationship between NP and Webo. 

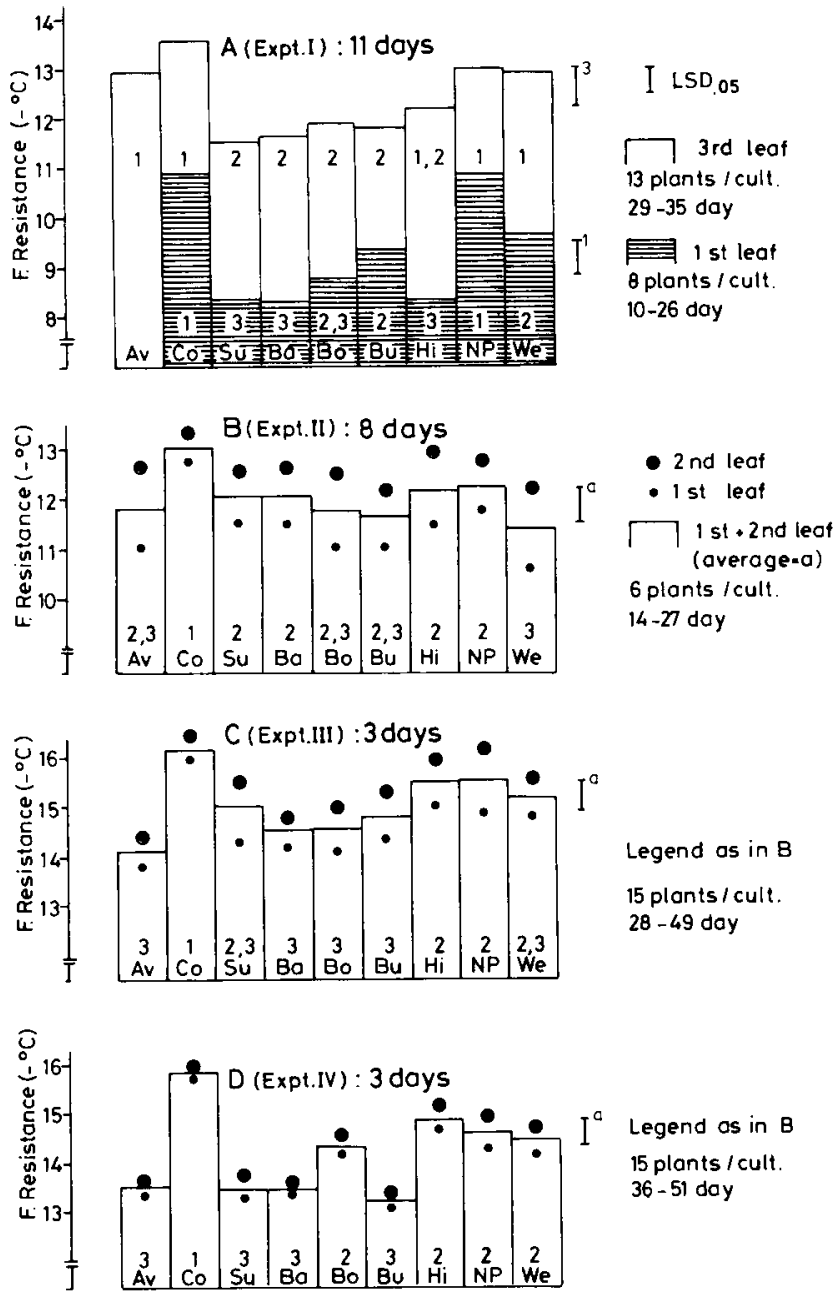

Fig. 3. Varietal * expression of acquired freezing resistance in the lowest leaves of hardened faba beans after different prehardening treatments $(A-D)(*$ varieties with 2 different numbers are significantly different; for details, see Materials and Methods).

Hence, available data of a larger number of hardened plants were compiled for a more accurate determination of varietal resistance ( 35 plants; Figure 4A). Côte d'Or proved to be superior to all the other varieties by a considerable margin $\left(1-2^{\circ} \mathrm{C}\right)$, followed by the German varieties Hiverna, NP and Webo (with a declining trend) and by the even less resistant British cultivars. The French cultivar Avrissot was most susceptible to freezing, whereas Survoy equalled the British in cultivars susceptibility. Although the level of acquired FR in partially dehardened plants was $>5^{\circ} \mathrm{C}$ lower than in hardened plants, their varietal rank pattern (45 plants; Figure 4B) was almost unchanged, apart from Survoy which was comparable to the British cultivars if hardened and to the

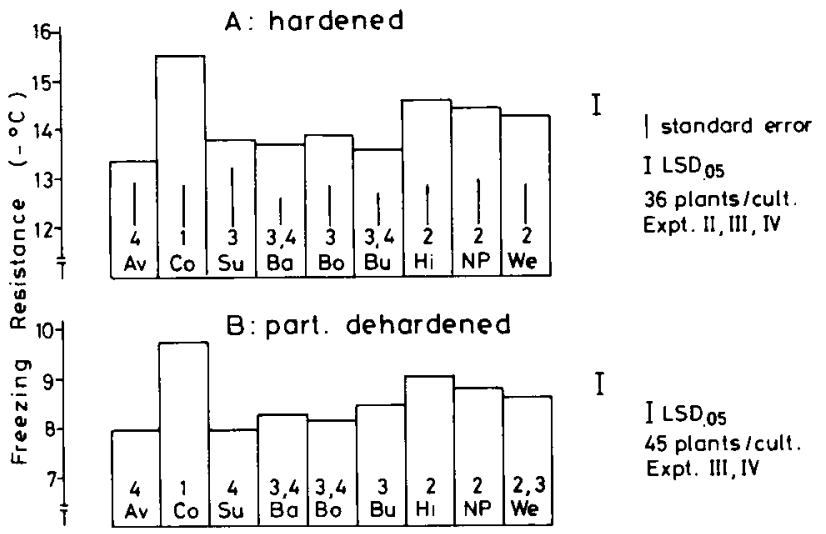

Fig. 4. Varietal * expression of acquired freezing resistance of hardened and partially dehardened faba beans (* varieties with 2 different numbers are significantly different; for details, see Materials and Methods).

least resistant Avrissot if partialy dehardened. Interestingly, the resistance of Survoy displayed the largest standard error of all varieties (1.09 and $1.15^{\circ} \mathrm{C}$ instead of $0.78-1.01$ and $0.85-1.06^{\circ} \mathrm{C}$ for hardened or unhardened plants, respectively).

\section{Discussion}

In the present study, hardening at $8 / 2^{\circ} \mathrm{C}$ in the first leaf of faba beans initially proceeded at a rate of $0.44^{\circ} \mathrm{C} /$ day, which was close to the rate recently observed for this crop (Herzog, 1987b) and which lay in a range comparable to other crops $\left(0.3^{\circ} \mathrm{C} /\right.$ day for peas: Swensen and Murray, 1983; $0.1-1.0^{\circ} \mathrm{C} /$ day for wheat: Willemot et al., 1972; Perras and Sarhan, 1984).

Evidence for a differential expression of FR among leaves or buds has been provided for several species (faba beans: Herzog, 1980, 1987b; Carex firma Host. L. and Sempervivum arachnoides L. Cernusca and Vesco, 1976; Fraxinus ornus L. Mair, 1968). Shortening the duration of pre-hardening during this study increased the final level of FR acquired by faba bean leaves and caused decreasing differences between the first 2 primary leaves. This response is attributable to the sequential ontogenesis of leaves underlined by the agreement of the differences in FR and the gradients of differentiation between these leaves observed at the onset of hardening: after 11 days of pre-hardening the first leaf was already fully expanded, the second was just unfolding and the third was still in the bud- 
stage, whereas after 3 days of pre-hardening unfolding of the first had just commenced and the second was still in the bud-stage.

Differential responses of leaves to hardening have also been observed in field grown winter faba beans (winter season 1986-1987, Experimental Station, Kiel, latitude $54^{\circ}, \mathrm{FRG}$ ). After an extremely mild autumn, early moderate frosts caused injuries (necroses) only on the stipules of the epicotyle of plants sown early; later on, the tirst and second bifoliate leaves were affected as well, but the third remained intact. After moderate to severe frost later in the season, this chain of events occurred even in plants sown later. Hence it can be concluded that autumn sowing should be postponed so that post-emergence temperatures in the neighbourhood of $15^{\circ} \mathrm{C}$ (i.e., pre-hardening, which limits the response to hardening) are avoided in order to minimize the risks of freezing injury.

Interpolated curves of the dehardening kinetic did not show any lag phase (Fig. 2). On the contrary, rates of decline in FR were obviously higher at the onset of dehardening than at later stages. The initial rate of decline clearly depended on the prevailing temperature; at $15^{\circ} \mathrm{C}$ it was 2.5 or 4 times as high as at $10^{\circ} \mathrm{C}$ and $8.5^{\circ} \mathrm{C}$, respectively. Exposure to $7^{\circ} \mathrm{C}$ led to only a very small decrease in FR over 3 weeks in partially dehardened plants. Since FR of almost entirely dehardened leaves even increased slowly at $9 / 5^{\circ} \mathrm{C}$ (day/night; expt. 7, data not shown), ambient temperatures around $7^{\circ} \mathrm{C}$, even if fluctuating, may be termed "non-dehardening" or, better still, "neutral". Hence mild periods of $>7^{\circ} \mathrm{C}$ which occasionally occur during winter in western Europe might have contributed to the risks of over-wintering in this region (Hauser and Böhm, 1984; Herzog, 1984).

With optimum hardening (cf., Fig. 3) a considerable degree of FR can be attained in faba bean varieties ranging from -14 to $-16^{\circ} \mathrm{C}$. However, since measurements were based on standardized freeze-thaw cycles with drops in temperature of $2^{\circ} \mathrm{C} / \mathrm{h}$ which are rarely observed during winter in western Europe, leaves may even endure harder frosts in the field. As reported by Picard et al. (1985), $60 \%$ of the plants in a stand of Côte d'Or and $14 \%$ of Bourdon survived $-25^{\circ} \mathrm{C}$ without any snow-cover in a field trial in eastern central France. This is in accordance with the superior performance of Côte d'Or in the present study. There were 3 lines of evidence for obvious difficulties faced by European breeders attempting to incorporate improved FR into new cultivars: (i) it was an old French land race which by far was the most resistant; (ii) German genotypes selected in winters often more severe than those prevailing in France of Great Britain displayed considerably higher FR than French or British genotypes; and (iii) no significant progress in FR has been made in new compared to old cultivars (Su vs. Av; $\mathrm{Ba}$ vs. $\mathrm{Bu} ; \mathrm{Hi}$ vs. We). Both moderate and often nonsegregative winters in western Europe, and the predominant allogamy of winter faba beans may have contributed to the obvious difficulties in improving FR and to the relatively high standard errors of varietal FR. A standard error of approximately $1^{\circ} \mathrm{C}$ necessitates the use of $>15$ plants in order to obtain reliable values of varietal FR. On the whole, results suggested considerable variation in maximum FR within and among European winter faba beans; however variation of an even larger degree was produced by the differential hardening response to pre-hardening conditions.

\section{Acknowledgments}

This study was supported by a grant from the Deutsche Forschungsgemeinschaft (DFG). I am grateful to Mrs. Thode and Mrs. Wohnsen for their skillful technical assistance.

\section{References}

Cernusca A. \& Vesco A. (1976) A thermoelectric heatflux controlled stage for measuring freezing parameters in small plants. Cryobiology 13,638-644

Hauser S. \& Böhm W. (1984) Erfahrungen und Möglichkeiten mit dem Anbau von Winterackerbohnen. Kali-Briefe 17(1), 39-52

Heath M.C. \& Hebblethwaite P.D. (1985) Agronomic problems associated with the pea crop. In : The Pea Crop (P.D. Hebblethwaite, M.C. Heath \& T.C.K. Dawkings, eds.), Butterworths, London, Boston, pp. 1929

Herzog H. (1980) Wachstumsverhalten und Kältetoleranz bei Ackerbohnen (Vicia faba L.) unter verschiedenen Testbedingungen. IV. Härtungsverlauf in Abhängigkeit von Organdifferenzierung von Sorten und verschiedenen Klimabedingungen. J. . Agron. Crop Sci. 149, 271-286

Herzog H. (1984) Probleme des Ackerbohnenanbaus. Schriftenreihe der Agrarwissenschaftlichen Fakultät der Universität Kiel 66, 58-66

Herzog H. (1987a) A quantitative method to assess freezing resistance in faba bean. J. Agron. Crop Sci. $158,195-204$

Herzog (1987b) Freezing resistance and development of faba beans as affected by ambient temperature, soil moisture and variety. J. Agron. Crop Sci. 159, 90-100 
Mair B. (1968) Frosthärtegradienten entlang der Knospenfloge auf Eschentrieben. Planta 82, 164-169

Perras M. \& Sarhan F. (1984) Energy state of spring and winter wheat during cold hardening. Soluble sugars and adenine nucleotides. Physiol. Plant. 60, 129-132

Picard J., Duc G. \& Pelletier R. (1985) Côte d'Or, a highly frost resistant population of Vicia faba. Fabis
$13,11-12$

Swensen J.B. \& Murray G.A. (1983) Cold acclimation of field peas in a controlled environment. Crop Sci. 23, 2730

Willemot C., Hope H.J., Williams R.J. \& Michaud R. (1977) Changes in fatty acid composition of winter wheat during frost hardening. Cryobiology 14, 87-93 